\title{
Mutaba'ah Pocket: A Design of Islamic Android Application for Student Self-Management
}

\author{
Caraka Putra Bhakti ${ }^{1}$, Khilda Wulidatin Noor ${ }^{2}$, Muhammad Alfarizqi Nizamuddin \\ Ghiffari $^{3}$, Emilia Nurpitasari ${ }^{4}$ \\ ${ }^{1,3,4}$ Guidance and Counseling, Ahmad Dahlan University, Yogyakarta, Indonesia, ${ }^{2}$ Guidance and \\ Counselin, Al Ikhlas Islamic Junior High School, Jakarta, Indonesia \\ *caraka.pb@bk.uad.ac.id
}

\begin{abstract}
This research aims to create an Android application that helps students manage themselves by applying Islamic elements in it. In the era of the industrial revolution, 4.0 self-management became one of the things that needed to be had to help someone in solving various problems. Self-management needs to be instilled since middle school because adolescents have unstable conditions emotionally, personality, and thoughts often experience changes. In managing oneself, the need for proper training and development. Self-management already exists in Islam's teachings, which consists of 3 things, namely aqidah, Syariah, and akhlak. If someone has the essence, then that person will be able to manage themselves optimally. With the convenience of current technology, self-management training can be implemented in a free form such as Android. "Mutaba'ah Pocket" is an application that incorporates the essence of Islam to help students manage themselves. This study uses an R\&D model, which is still in the initial design phase. It is hoped that this application can help students manage themselves optimally.
\end{abstract}

Keywords: Self-Management; Islamic Guidance and Counseling; Mutaba'ah; Revolution Industriy 4.0; Android Aplication

\section{Introduction}

The world in general, and Indonesia in particular, is entering a new industrial era marked by the era of digitalization in various sectors of life. Experts call this the era of the industrial revolution 4.0 [1]. If the resources in Indonesia do not have sufficient competence, humans will likely find it challenging to adapt. Humans' role will shift to become managers and users of technology in the industrial revolution of 4.0 [2]. So it is necessary to know this era and learn more about what is needed in this era.

Borrowing research results from McKinsey in 2016 that the impact of digital technology towards the industrial revolution 4.0 in the next five (5) years, there will be 52.6 million types of jobs that will experience a shift or disappear from the face of the earth [3]. This study's results give the message that every person who still wants to have a self-existence in global competition must prepare self-management, mentality, and skills that have a competitive advantage from others [4].

21 st Century learning demands are relevant, bearing in mind the development of 4IR, which, if observed continuously, reduces routine human function. Higher-level thinking skills, 
including metacognition, are essential to be comprehensively taught because they are an essential component in student self-management learning. In this case forming independent students which are the ultimate goal of learning that is proclaimed in the National Research Council of the National Academies because metacognition teaches students to reflect on the process of thinking about how to understand problems, develop strategies for solving and reflecting mistakes through an accurate assessment to make the right decision [5].

The period of social transition in adolescents experiences changes in individual relationships with other humans, namely in personality, emotions, and social contexts in development. Disputing parents, aggressive attacks, adolescent happiness in individual events, and gender roles in society reflect the role of emotional, social processes in adolescent development [6]. Therefore we need the ability to self-manage or self-management in the development process of adolescence. [7], where if it is not supported by excellent skills selfmanagement, it will not be able to achieve optimal achievement and development.

Self-management or self-regulation is the ability of a person to bring up and monitor their thoughts, feelings, and behavior to achieve a specific goal. In this case, it is the purpose of learning [8]. Self-management is essential in achieving learning goals, especially in subjects that are classified as severe and require high analysis, for example, chemistry, mathematics, and physics lessons to set targets for achievement, organize, plan and direct themselves to achieve maximum achievement.

Hoare argued that self-management is one of 33 types of self in humans that need to be developed early. Furthermore, Yates suggested that self-management is a process carried out by individuals in directing their behavior by using a strategy or a combination of therapeutic strategies to be able to behave positively and productively. Self-management is a method commonly used in the tradition of guidance and counseling. Its use can be subject to various behavioral goals [9].

Self-management is an easy and inexpensive form of exercise. Self-management is very useful and efficient when applied in schools to help students who experience various problems due to a lack of self-knowledge. Self-management is very supportive of changing the pattern of bad habits of students. Self-management is also a form of student behavior responsible for managing all of their behavior, with the aim that students can be more independent, more independent, and can predict their future.

As a guidance and counseling teacher, it is not uncommon to deal with students who experience difficulties in personal, learning, career, and social matters. On the other hand, guidance and counseling have a useful role in optimizing the potential of students. Guidance and counseling help students to accept, direct, understand, realize with their decision responsibilities and make decisions to achieve wealth and happiness [10]. In this activity, the BK teacher's role is related to students, namely motivating students, especially in terms of self-management. Concerning guidance and counseling in schools, one of the crucial tasks of BK teachers in schools is to encourage students to manage self-management.

Therefore, guidance and counseling teachers need to optimize student self-management based on a strong foundation, such as using values in Islam. As time goes by, it is necessary to implement self-management development given by BK teachers through media such as Android applications. 


\section{Literature Review}

\section{A. Self-Management}

Self-management is a tool to channel the desire to meet one's competency needs that affect one's success in undergoing his educational process, where to achieve it requires achievement motivation [11]. Similarly, the ability to organize themselves and direct themselves. The ability to self-regulate can prevent individuals from indulgence or personality lapses. In selfmanagement, it is expected that students can manage, monitor, and evaluate themselves to achieve changes in behavior habits that are better. [12].

Self-management has benefits for students, including children, able to face challenges and problems in their daily lives wisely. On the other hand, self-management make the student have a high sense of responsibility for their actions, help children reach their goals, and help children manage themselves both words and deeds it does. In guidance and counseling, to develop self-management has factors that need to be considered, namely [13]:

1. There is a combination of several counseling strategies in which some of them focus on antecedents and others on the consequences of certain behaviors;

2. Consistency in using one strategy over a certain period;

3. Evidence of self-evaluation, goal setting with high standards;

4. Use self-management privately, verbally or with certain forms of material; and

5. External/environmental support.

\section{B. Teenager Student's Characteristic}

Adolescence is a period in human life whose age and role are often not very clear. Adolescence is often considered a transitional period, where the times when children no longer want to be treated as children but seen from their physical growth, it can not be said of an adult.

The phases of adolescence (puberty), according to Monks et al. [14] that is between the ages of 12-21 years, with a division of 12-15 years including early adolescence, 15-18 years including middle adolescence, 18-21 years including late adolescence.

Characteristics of teenagers can be seen in several aspects, namely physical growth, sexual development, ways of thinking causality, overflowing emotions, social development, moral development, and personality development.

Adolescents are expected to understand themselves better and be understood by others to undergo adult preparation smoothly. By utilizing all available opportunities, an integrated personality is formed to adapt to the environment.

\section{Islamic Core (Aqidah, Akhlak, Syariat)}

Islam teaches various things that humans need to live in the world. In Islam consists of 3 main principles, namely Aqeedah, Syariat, and Akhlak [15]. Every human being must possess these three main things. The explanation is as follows.

1) Aqidah

Aqidah is the core of every human being to behave. Aqeedah is closely related to the bond of one's heart in believing in God. According to the terminology, aqidah is a firm and absolute faith, not mixed with the slightest doubt for those who believe it [16]. Aqidah is related to the belief and belief in one's heart towards God in living life. Aqidah becomes one of the main things in humans. Citing Hasbi Ash Shiddiqiey Like a building, aqidah is the foundation, while other Islamic teachings are something built on it [17]. 


\section{2) Akhlak}

Akhlak is related to the nature and patterns of thinking of someone in behavior. Akhlak is all human habits that originate in oneself that are driven consciously and manifested in good deeds [18]. If someone has good akhlak, then that person will not behave deviant. Akhlak is because morality is a measure of the personality of a Muslim [19]. Thus, Akhlak is related to the nature and habits of a person who is carried out daily.

\section{3) Syariat}

Syariat is a way of behaving, acting, or doing activities that are good in Islam. In terms of sharia is a set of Divine norms that regulate human relations with God, humans with each other in social, and humans with other creatures [20]. The Syariat includes clear rules so that each person whose activities will have a positive effect because according to the rules. Because of the flexibility of Islamic law and ensure the suitability of its application in human life [21].

\section{Android Aplication}

Android was chosen because it is a digital platform that can be used in learning. Learning using an android application can provide advantages, namely multitasking, and drawbacks, namely overload [22]. Despite its shortcomings, Android can be a mobile platform that is easier to use and is an option nowadays because many people use it. Android is a Linux-based opensource operating system designed for touch screen mobile devices such as smartphones and tablet computers [23]. Through an open android platform, developers can create applications [24]. Thus, Android becomes a platform that makes it easy for developers to create applications as they wish.

\section{Methodology}

This study uses the research and development $(\mathrm{RnD})$ research model. Research and development methods are used to produce a particular product and test its effectiveness [25]. Thus, RnD was chosen as the research model in this study, where the final goal is to produce a product.

The RnD study consisted of several activities, including Planning, Preliminary Design, Initial Production, and limited trials. In the planning stage, the researcher gathers various information and things that will be included in the application. The content material is obtained from primary and secondary sources such as journals, books, and experts. In the initial design phase, the initial design is related to the application form and components in the application.

After being designed, the next step is to carry out a production process in which the production process is reviewed in terms of whether the components and content follow the students' needs. At the production stage, Android application development uses Adobe Flash CS6 ${ }^{\circledR}$ software. Then conduct a limited test to students. However, at present, research only reaches the initial design stage. The technical research plan is as follows. 
Table 1. Research Design Activities

\begin{tabular}{ll}
\hline Research Stages & Activities \\
\hline Planning & Collecting resources related to self management and \\
& Islam (Akhlak, Aqidah, Shariah) \\
Preliminary Design & $\begin{array}{l}\text { Designing the form and appearance of the } \\
\text { application to be developed include: initial }\end{array}$ \\
& appearance, content, and worksheets \\
Production & $\begin{array}{l}\text { Develop applications using Adobe Flash CS6® } \\
\text { software } \\
\text { Limited trial }\end{array}$ \\
$\begin{array}{l}\text { Conducting limited trials on students, especially in } \\
\text { adolescents related to the effectiveness of the } \\
\text { application }\end{array}$ \\
\hline
\end{tabular}

\section{Result and Discussion}

\section{E. Self-Management on Islamic Studies}

Self-management is an ability that is used by someone in managing themselves to face various things in life. However, this self-management is very much related to Islam. Islamic teachings cover all aspects of human life [21]. Besides, Islam has the main core, which regulates human behavior.

Aqidah, Akhlak, and Syariat teach humans how to behave from the beginning of waking up to going back to sleep in the right conditions and conditions. Therefore, when someone has aqidah, akhlak, and behaves, according to Syariat, then he will be awake and always behave positively. Someone will be able to manage themselves in a state of Islam that is awake.

In Islam, humans will be bound by a rule which must be done with a sincere heart. Aqidah is what someone believes. If someone has the right Aqidah, it will be free from doubt [26]. Here the concept of Aqidah makes humans manage themselves in terms of ordinary and rules without coercion.

Furthermore, in Islam, humans need to have the right attitude of thoughts and deeds. The concept of akhlak is a trait contained in the soul, both innate or effort, that results in good behavior [27]. Also, morality is one of the teachings of Islam that must be possessed by every Muslim individual is living his daily life [19]. Thus, related to attitudes, the concept of morality manages themselves so that they can be appropriately controlled under what is in themselves.

Of course, in behaving every day, small things need to be considered to provide maximum benefits. Syariat is built on two things. First, the obligation of humans to give thanks for Allah's blessings. Second, the opportunity to feel all the deliciousness of Allah's blessings [28]. Syariat is shown in the behavior according to the rules for the good of humans. Sharia is only for the benefit of humans. If there is something that brings harm to humans, it certainly is not Islamic law [29]. Here this concept, the Syariat teaches about the ethics of how humans manage good behavior.

Thus, self-management has a secure connection with Islam. In Islam, what aspects need to be maintained in managing themselves have been explained and aspects of self-management in general. Therefore, the whole concept of self-management can be seen in Islamic teachings.

\section{F. Mutaba'ah Pocket: Islamic Self-Management Android Application}

In developing self-management using Islamic teachings, this mutaba'ah pocket provides a variety of features in which each feature in this application represents every aspect of Islam's 
three main principles. The name mutaba'ah was chosen because it means "to follow" and "supervise," which means to follow and supervise in carrying out an activity according to plan. The material in the mutaba'ah pocket is as follows.

Table 2. Application Lesson Material

\begin{tabular}{ll}
\hline Material Aspects & Material \\
\hline Aqidah & There is material related to what is aqidah and why is \\
& important \\
& Examples in the form of videos or pictures related to how to \\
& apply aqidah \\
& Daily tasks related to aqidah in the form of a checklist of \\
& worship activities \\
& explanation related to Akhlak \\
& examples of videos and images relating to good Akhlak \\
Akhlak & Daily tasks that show good Akhlak (examples) \\
& Explanation related to Syariat in daily life \\
Syariat & Syariat things need to be done in accordance with Islamic \\
& various kinds of rules of doing daily activities according to \\
& Islamic Syaiat \\
\hline
\end{tabular}

Each material is entered into an android application where the design is adjusted to the activity in the material. The design is designed as follows.

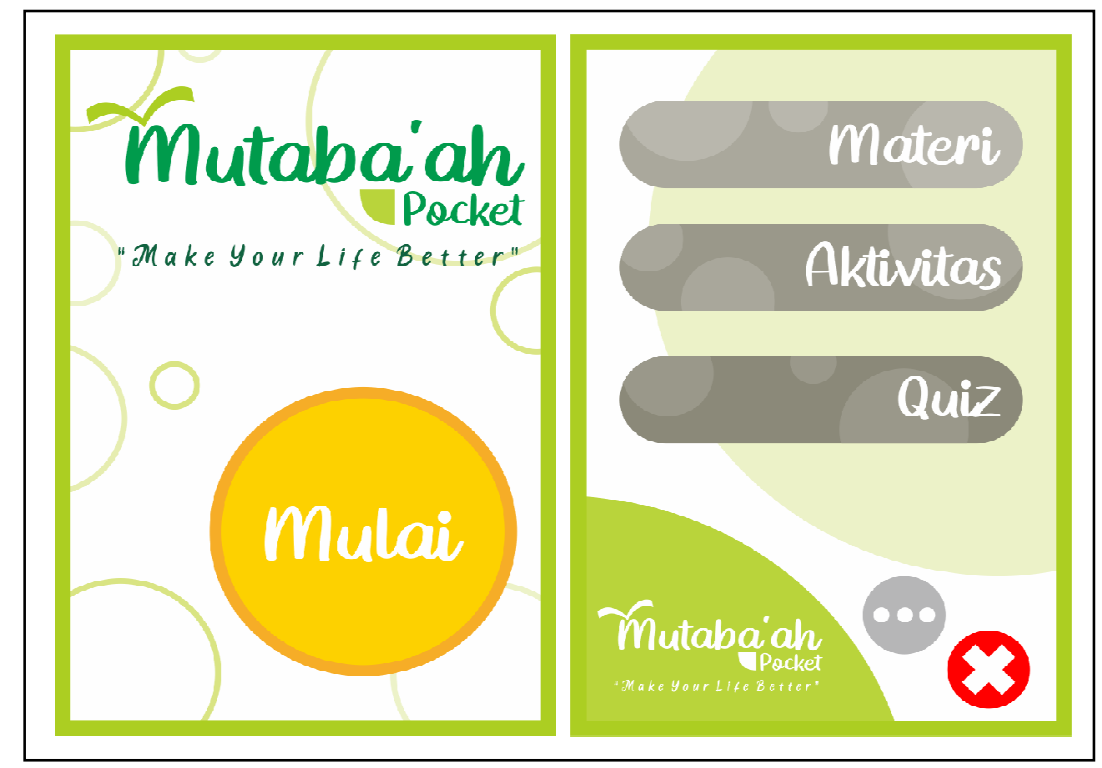

Figure. 1. Start and menu

After entering into the application, students who use this application will be given a variety of menus. 


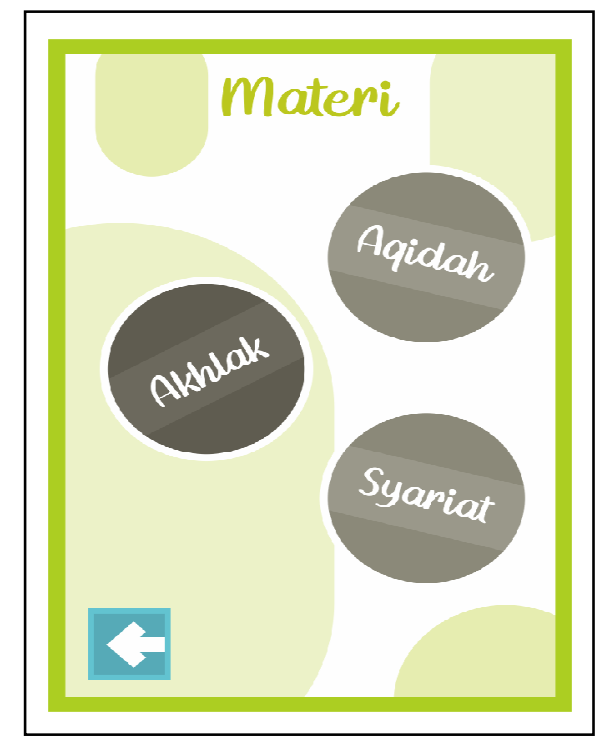

Figure. 2. Main material of islamic self-management

Furthermore, students who use this application are welcome to choose one of the following material cores.

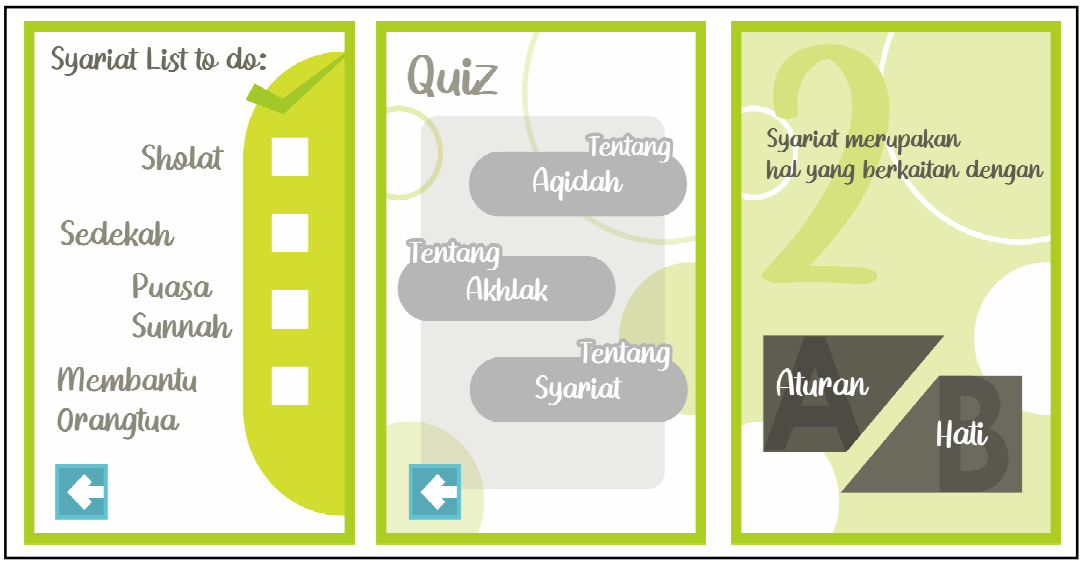

Figure. 3. some activities self-management activities

When choosing one primary material, there are various activities such as material explanation, daily tasks, and evaluation.

This application will help students manage themselves every day with a variety of activities that need to be carried out gradually. Parents and homeroom teachers at school can see the whole activity. Information obtained related to student development will provide further intervention for teachers or parents to educate students. Data and activities carried out by students will be recorded and will be stored in a database. The database used is still using a simple system using Google Form ${ }^{\circledR}$ and Google Drive ${ }^{\circledR}$. 


\section{Conclusion}

Instilling Self-management needs to be instilled since adolescence. Because adolescents have very volatile conditions. Besides, self-management is something that is needed in the era of the industrial revolution of 4.0. However, besides strong self-management, it is also necessary to prioritize Islam as a basis for self-management. Self-management needs to be established since adolescence, and the role of BK teachers is essential in optimizing students' potential in self-management. One of BK teachers' efforts in optimizing student selfmanagement is to use technology that is following the times. mutaba'ah pocket is expected to be an alternative android application that can be used for bk teachers in developing student self-management. Various features presented will optimize student self-management with Islamic values in it. Hopefully, this application can be produced immediately in the future, and limited testing is carried out.

\section{References}

[1] K. Chun, H. Kim, and K. Jang, Analysis on Research Level of the Five Major Platform Technologies Related to the Fourth Industrial Revolution. 2017.

[2] B. Astuti, R. Lestari, and C. P. Bhakti, "Student Decision-Making Ability As A Preparation For Facing The Industrial Revolution 4.0," Int. J. Sci. Technol. Res., vol. 8, no. 10, pp. 1200-1204, 2019.

[3] M. Kinsey, Digital tecnology menuju revolusi industri 4.0. Digit. Tecnol, 2016.

[4] G. Stonehouse and B. Snowdon, "Competitive advantage revisited Michael Porter on strategy and competitiveness," J. Manag. Inq., vol. 16, no. 3, pp. 256-273, 2007, doi: $10.1177 / 1056492607306333$.

[5] National Research Council for 21st Century Skills: A framework for k-12 science education: Practices, Crosscutting Concepts, and Core Ideas. Washington DC: The National Academies Press, 2010.

[6] Suntrock, Adolescence. Jakarta: Erlangga, 2003.

[7] Slameto, Belajar dan faktor-faktor yang mempengaruhinya. Jakarta: Rineka Cipta, 2010.

[8] N. Adicondro and A. Purnamasari, "Efeikasi Diri, Dukungan Sosial Keluarga dan Self Regulated Learning pada siswa kelas VIII," Humanitas (Monterey. N. L)., vol. 8, no. 1, pp. 17-27, 2012, doi: 10.26555/humanitas.v8i1.448.

[9] M. Abdurrahman, Pendidikan bagi Anak Berkesulitan Belajar. Jakarta: Rineka Cipta, 2007.

[10] C. P. Bhakti and F. A. Rahman, "Android application development of exploration career based on Multiple Intellegence: A model hypothetical Android application development of exploration career based on Multiple Intellegence: A model hypothetical," in The 7th South East Asia Design Research International Conference (SEADRIC 2019), 2020, pp. 1-11, doi: 10.1088/1742-6596/1470/1/012043.

[11] B. I. Sappaile, "Hubungan Kemampuan Penalaran dalam Matematika dan Motivasi Berprestasi terhadap Prestasi Belajar Matematika," J. Pendidik. dan Kebud., vol. 13, no. 69 , pp. 985-1003, 2007, doi: 10.24832/jpnk.v13i69.345.

[12] M. A. Monica and R. A. Gani, "Efektivitas Layanan Konseling Behavioral dengan Teknik Self-Management untuk Mengembangkan Tanggung Jawab Belajar pada 
Peserta Didik Kelas Xi SMA Al-Azhar 3 Bandar Lampung Tahun Ajaran 2015/2016," KONSELI J. Bimbing. dan Konseling, vol. 3, no. 2, pp. 113-126, 2016.

[13] Hartono and B. Soedarmadji, Psikologi Konseling Edisi Revisi. Jakarta: Kencana Prenada Media Group, 2012.

[14] F. J. Monks, A. M. P. Knoers, and S. R. Haditono, Psikologi Perkembangan: pengantar dalam berbagai bagiannya. Yogyakarta: Gadjah Mada University Press, 2002.

[15] N. R. B. Aji Kamaruddin Salleh, "Kefahaman Asas-Asas Akidah Saudara Baru berdasarkan Sukatan Bimbingan di Pusat Dakwah Islamiah Temburong," in Kolokium Antarabangsa Siswazah Pengajian Islam 2016, 2016, pp. 1-16.

[16] A. Atabik, "Corak Tafsir Aqidah ( Kajian Komparatif Penafsiran Ayat-ayat Aqidah )," Esensia, vol. 17, no. 2, pp. 209-223, 2016.

[17] P. A. Karim, "Fungsi Aqidah dan Sebab-sebab Penyimpangan dalam Aqidah," NIZHAMIYAH J. Pendidik. Islam dan Teknol. Pendidik., vol. 7, no. 1, pp. 33-42, 2017.

[18] S. B. Raharjo, "Pendidikan Karakter Sebagai Upaya Menciptakan Akhlak Mulia," J. Pendidik. dan Kebud., vol. 16, no. 3, pp. 229-238, 2010.

[19] Y. Suryadarma and A. H. Haq, "Pendidikan Akhlak Menurut Imam Al-Ghazali," J. At-Ta'dib, vol. 10, no. 2, pp. 361-381, 2015.

[20] D. R. Juwita, "Pemberlakukan Hukum Syariat bagi Warga Non Muslim di Daerah Nangroe Aceh Darussalam (Perspektif Islam dan HAM )," El-Wasathiya J. Stud. Agama, vol. 4, no. 1, pp. 23-38, 2016.

[21] R. Fahlefi, "Implementasi Maṣlaḥah dalam Kegiatan Ekonomi Syariah,” JURIS, vol. 14, no. 2, pp. 225-233, 2015.

[22] Tim EMS, Pemprograman Android dalam Sehari. Jakarta: PT elex media Komputindo, 2015.

[23] Nazruddin Safaat H, Android: Pemrograman Aplikasi Mobile Smartphone dan Tablet PC Berbasis Android (Edisi Revisi). 2012.

[24] Murtiwiyati and G. Lauren, "Rancang Bangun Aplikasi Pembelajaran Budaya Indonesia Untuk Anak Sekolah Dasar Berbasis Android,” J. Ilm. KOMPUTASI, vol. 12, pp. 1-16, 2013.

[25] Sugiyono, Metode Penelitian Pendidikan: Pendekatan Kuantitatif, Kualitatif dan $R \& D$. Bandung: Alfabeta, 2011.

[26] R. F. Lubis, "Menanamkan Aqidah dan Tauhid kepada Anak Usia Dini," J. AlAbyadh, vol. 2, no. 2, pp. 82-91, 2019.

[27] A. Maulida, "Konsep dan Desain Pendidikan Akhlak dalam Islamisasi Pribadi dan Masyarakat," Edukasi Islam. J. Pendidik. Islam, vol. 2, pp. 358-375, 2013.

[28] L. Jamaa, "Konsep Ta'abbudi dan Ta'aqquli dan Implikasinya terhadap Perkembangan Hukum Islam," Asy-Stir'ahJurnal Ilmu Syariah dan Huk., vol. 47, no. 1, pp. 1-26, 2013.

[29] M. N. Harisudin, "Formulasi Baru Epistemologi Fiqh Perempuan," Al-ihkam, vol. 10, no. 2, 2015 . 